\title{
LC-MS/MS を用いた豆類中残留農薬の迅速分析法に関する研究
}

(平成 28 年 4 月 28 日受理)

$\begin{array}{ccccc}\text { 岩越景子* } & \text { 大塚健治 } & \text { 田村康宏 } & \text { 富澤早 苗 } & \text { 増㴊 珠子 } \\ \text { 八巻ゆみこ } & \text { 中川由紀子 } & \text { 増田諒子 } & \text { 須藤 将太 } & \text { 小鍛治好恵 } \\ & & \text { 新藤 哲也 } & \text { 高野伊知郎 } & \end{array}$

Rapid Multi-Residue Analysis of Pesticides in Pulses by LC-MS/MS

Keiko Iwakoshi*, Kenji Otsuka, Yasuhiro Tamura, Sanae Tomizawa, Tamako Masubuchi, Yumiko Yamaki, Yukiko Nakagawa, Ryoko Masuda, Shota Suto, Yoshie KoKaJI, Tetsuya Shindo and Ichiro Takano

Tokyo Metropolitan Institute of Public Health: 3-24-1 Hyakunin-cho, Shinjuku-ku, Tokyo 169-0073, Japan;

*Corresponding author

Rapid multi-residue analysis of pesticides in pulses was developed using LC-MS/MS. Pesticide residues in $5 \mathrm{~g}$ of homogenized pulses were extracted with $30 \mathrm{~mL}$ of acetonitrile and salted out with $4 \mathrm{~g}$ of anhydrous magnesium sulfate and $2 \mathrm{~g}$ of sodium chloride in the presence of citrate buffer in a disposable tube. The resulting residues were extracted with $30 \mathrm{~mL}$ of acetonitrile, and co-extractives were removed on a handmade four-layer column, consisting of a layer of Z-Sep/C18 $(20 \mathrm{mg} / 50 \mathrm{mg})$ dry particles on top of a three-layer, custom-made (pre-packed) column (lower bed: $60 \mathrm{mg}$ of PSA, middle bed: $30 \mathrm{mg}$ of GC, and top bed: $60 \mathrm{mg}$ of C18) packed in a $10 \mathrm{~mm}$ internal diameter polypropylene column $(3 \mathrm{~mL})$. The developed method showed good recoveries of pesticides in soybean, lentil, white kidney bean and garbanzo. According to the method validation guideline of the Ministry of Health, Labour and Welfare of Japan, recovery tests were conducted in soybeans fortified with $107 \mathrm{kinds}$ of pesticides at the levels of 0.01 and $0.1 \mu \mathrm{g} / \mathrm{g}$, respectively. At each concentration 2 samples were extracted on 5 separate days. Pesticides in the test solution were determined by LC-MS/MS using scheduled MRM. As regards the trueness of this method for 107 pesticides in soybeans, 97 pesticides were in the range of 70-120\% with satisfactory repeatability and within-run reproducibility. This new method is expected to be applicable for routine examination of pesticide residues in soybeans.

(Received April 28, 2016)

Key words: 残留農薬 pesticide residue; 多成分一斉分析 multi-residue analysis; 農産物 agricultural product; 大豆 soybean; 豆類 pulse; 固相抽出 solid-phase extraction; 液体クロマトグラフ-タンデ 么型質量分析計 LC-MS/MS

付録資料：付録資料（付録図Table S1, Table S2 はJ-Stageの日本食品衛生学雑誌（http://dx.doi. org/10.3358/shokueishi.57.150）で閲覧できる。

\section{緒言}

食品中の残留農薬分析では, 食品衛生法の改定に伴うポ ジティブリスト制度が導入され，さらに農薬等の規格基準 への適合性について判断を行う試験については,「食品中 に残留する農薬等に関する試験法の妥当性評価ガイドライ ン」*1が通知された. 現在, 規制対象となる農薬について

*連絡先 Keiko_Iwakoshi@member.metro.tokyo.jp 東京都健康安全研究センター： テ169-0073 東京都新宿区 百人町 3-24-1
は 800 以上が該当し，それらの農薬についてガイドライン に従って評価を実施するためには，正確でかつ迅速性の高 い分析法の開発が必要である。これまでに筆者らも，多く の食品に適応可能な分析法を開発し，その妥当性を評価し てきた ${ }^{1)}$.

しかし，食品中のさまざまな成分は，分析を妨害するこ

*1 厚生労働省医薬品局食品安全部長通知 “食品中に残留する農 薬等に関する試験法の妥当性評価ガイドライン（平成 19 年 11月 15 日食安発第1115001号)，一部改正について (平成 22 年 12 月 24 日食安発 1224 第 1 号)” 
とや, 分析機器の流路を污染して感度を低下させることが あった，特に大豆等を含む豆類については，脂質の影響が 大きく, 残留農薬分析での課題となっている。一部にマト リックス検量線を採用して改善する方法 ${ }^{2)}$ はあるものの, 絶対検量線での定量は困難とされている，筆者らも，既 法 ${ }^{1)}$ を用いて，大豆を含む豆類について分析したところ， 十分な真度を確保することができなかった。

一般的に脂質を多く含む食品における残留農薬分析で は, ゲル浸透クロマトグラフィー $(\mathrm{GPC})^{3)}$, 低温抽出 法 $^{4), 5)}$, 固相抽出 ${ }^{6)}$ 等による精製が必要とされている. し かし，GPCでは多量の有機溶媒が必要となり，また，高 分子量の農薬が保持できないといった問題がある ${ }^{3)}$. 冷凍 保存等による低温抽出法では, 時間を要する割には油分が 十分除去できないなどの報告例がある ${ }^{4), 5)}$.

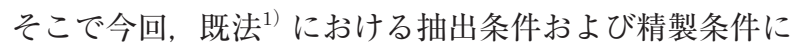
改良を加え, 大豆を含む豆類についてのより効果的な分析 法を確立したので報告する。

\section{実 験 方 法}

\section{1. 試料}

市販の大豆 (日本産), レンズ豆 (アメリカ産), 白いん げん豆 (アメリカ産)，ひよこ豆（アメリカ産）を使用し た、いずれも今回検討する農薬は含まれていないことを確 認した後, 実験に供した.

\section{2. 試薬および標準品}

分析対象農薬として, 農薬混合標準溶液8種およびアミ ノカルブは, 関東化学 (株) 製の残留農薬試験用, イソカル ボホスはSIGMA-ALDRICH ${ }^{\circledR}$ 社製の残留農薬試験用を使 用した。標準原液は, 各農薬標準品をアセトニトリルで溶 解して $1,000 \mu \mathrm{g} / \mathrm{mL}$ とした. $10 \mu \mathrm{g} / \mathrm{mL}$ の農薬混合標準溶 液（アセフェートおよびメタミドホスについては $50 \mu \mathrm{g} /$ $\mathrm{mL}$ ）は，各農薬の標準原液 $1 \mathrm{~mL}$ 混合してアセトニト リルで $100 \mathrm{~mL}$ に定容した。また検量線は，標準溶液をア セトニトリル $/$ 水 $(1: 1)$ で適宜希釈して $5.0 \times 10^{-4} \sim 5.0$ $\times 10^{-2} \mu \mathrm{g} / \mathrm{mL}$ (アセフェートおよびメタミドホスについ ては $\left.2.5 \times 10^{-3} \sim 25.0 \times 10^{-2} \mu \mathrm{g} / \mathrm{mL}\right)$ の範囲で作製した。

無水硫酸マグネシウム, クエン酸水素 2 ナトリウム 1.5 水和物, クエン酸 3 ナトリウム 2 水和物, 塩化ナトリウム は和光純薬工業(株)製の特級品を用いた。 アセトニトリ ル, メタノール, 酶酸アンモニウムは和光純薬工業(株)製 のLC/MS用を用いた。水はMerck Millipore社製Milli-Q Integralの超純水を用いた。

固相抽出カラムは, 既法 ${ }^{1)}$ で用いたジーエルサイエンス 社製 (特注品) に, SIGMA-ALDRICH ${ }^{\circledR}$ 社製のZ-Sep/C18 (20 mg/50 mg) dSPE CLEAN-UP TUBEを使用時に積層 したもの（以下；ジルコニア含有積層カラム）を用いた (Fig. 1).

\section{3. 装置および分析条件}

LC：Waters社製ACQUITY UPLC, MS/MS：Waters社 製Xevo TQD，カラム：CAPCELL PAK C18 AQ $(3.0 \mu \mathrm{m}$,

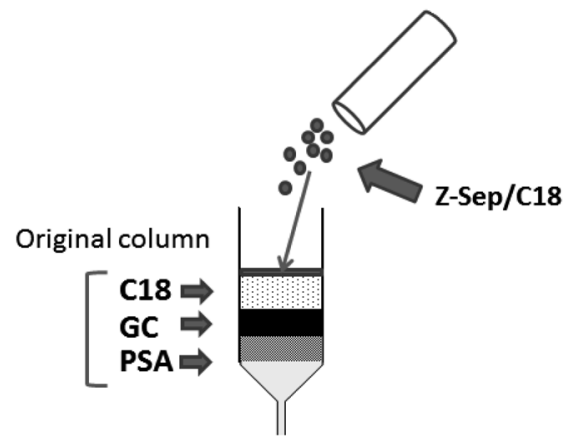

Fig. 1. Structure of the handmade SPE column

$$
\begin{aligned}
& \text { A four-layer column, with a layer of Z-Sep/C18 } \\
& (20 \mathrm{mg} / 50 \mathrm{mg}) \text { dry particles on top of a three-lay- } \\
& \text { er, custom-made (pre-packed) column (lower bed: } \\
& 60 \mathrm{mg} \text { of PSA, middle bed: } 30 \mathrm{mg} \text { of } \mathrm{GC} \text {, and top } \\
& \text { bed: } 60 \mathrm{mg} \text { of C18) packed in a } 10 \mathrm{~mm} \text { internal di- } \\
& \text { ameter polypropylene column }(3 \mathrm{~mL}) \text {. }
\end{aligned}
$$

$2.0 \mathrm{~mm}$ i.d. $\times 150 \mathrm{~mm}$ ), カラム温度： $40^{\circ} \mathrm{C}$, 移動相： $\mathrm{A}$; $0.5 \mathrm{~mol} / \mathrm{L}$ 酢酸アンモニウム含有水溶液, $\mathrm{B} ; 0.5 \mathrm{~mol} / \mathrm{L}$ 酢 酸アンモニウム含有アセトニトリル，グラジエント条件： $[\mathrm{A} ; 100 \%(0 \mathrm{~min}) \rightarrow 5 \%(20 \rightarrow 30 \mathrm{~min}) \rightarrow 0 \%(30.1 \rightarrow 40$ $\mathrm{min}$ ), 流量: $0.2 \mathrm{~mL} / \mathrm{min}$, 注入量： $2 \mu \mathrm{L}$, イオン化: ESI 十, キャピラリー電圧： $0.5 \mathrm{kV}(+)$, デゾルベーションガ ス温度： $400^{\circ} \mathrm{C}$ 。なお, MRMトランジションをTable S1 に示した。

\section{4. 試験液の調製}

パナソニック社製ファイバーミキサーのミルを用いて細 かく粉砕し，均一化した試料 $5 \mathrm{~g}$ を $100 \mathrm{~mL}$ 容量のIWAKI 社製ポリプロピレン製遠心管に採り，水を $10 \mathrm{~mL}$ 加え， 30 分間放置した。これに，アセトニトリル $30 \mathrm{~mL}$ を加え， マイクロテック・ニチオン社製シャフト型ホモジナイザー で1分間ホモジナイズした後，無水硫酸マグネシウム $4 \mathrm{~g}$, クエン酸 3 ナトリウム 2 水和物 $1 \mathrm{~g}$, クエン酸水素 2 ナトリ ウム 1.5 水和物 $0.5 \mathrm{~g}$ ，塩化ナトリウム $2 \mathrm{~g}$ を加えてガラス 製のかく拌棒を用いて 1 分間かく拌し，さらに手振りで振 とうした。 その後, 遠心分離 $\left(1,800 \times g, 10 \mathrm{~min}, 4^{\circ} \mathrm{C}\right)$ し てアセトニトリル層を分取した。残留物に，アセトニトリ ル $30 \mathrm{~mL}$ 加え，1分間かく汼，振とうし，同条件で遠心 分離した後，アセトニトリル層を分取し，両液を合わせて $80 \mathrm{~mL}$ に定容した

Fig. 1に示すジルコニア含有積層カラムを，アセトン $2 \mathrm{~mL}$ ，トルエン／アセトニトリル $(1: 3)$ 混液 $9 \mathrm{~mL}$ でコ ンディショニングした後, 上記抽出液のうち $4 \mathrm{~mL}$ を負荷 し，さらに，トルェン／アセトニトリル $(1: 3)$ 混液 $5 \mathrm{~mL}$ を加えて自然落下にて溶出した。全溶出液を窒素気 流下で乾固後, LC/MS用アセトニトリル $0.5 \mathrm{~mL}$ に溶解し た。その液に超純水 $0.5 \mathrm{~mL}$ を加え, LC-MS/MS 用試験液 （4倍希釈）とした. 


\section{結果および考察}

\section{1. 抽出法の検討}

アセトニトリル $30 \mathrm{~mL}$ を用いて, 45 農薬 $0.1 \mu \mathrm{g} / \mathrm{g}$ 添加 したときの大豆における回収率について，抽出回数 1 回の 場合は $40 \mathrm{~mL}, 2$ 回の場合は $80 \mathrm{~mL}$ に定容し, 抽出回数に よる違いを比較した。 その結果, 検討したすべての農薬 で，2回とすることで回収率が向上することが分かった (Fig. 2). また, 既法 ${ }^{1)}$ で使用していた塩化ナトリウム量 について添加量を 1〜 $4 \mathrm{~g}$ の範囲で比較したところ, $2 \mathrm{~g}$ と することで, 抽出時の水層と有機層が最もよく分離した. 以上のことから, 抽出回数を 2 回, 塩化ナトリウム添加量 を $2 \mathrm{~g}$ と設定した。

\section{2. 精製法の検討}

大豆を含む豆類には，多量の脂質が含まれることか $ら^{7)}$ ， 既法 ${ }^{1)}$ で使用したカラムのみでは，十分に除去でき ず，乾固後に油滴のようなものが認められた。また，脂質 等の夾雑成分により生じるLC-MS/MSでのイオン化抑制 により，絶対検量線での定量が困難であった。

そこで，モノアシルグリセロールや脂肪酸等の除去効果 が報告されている(1) ジルコニア結合型シリカゲルカラ ムの使用を試みた。

Z-Sep ${ }^{+}$とZ-Sep/C18（20 mg/50 mg）を比較したとこ ろ, Z-Sep ${ }^{+}$では検討した農薬のほとんどで十分な回収率 および精度が得られなかった。 また，ほかの報告例 ${ }^{11)}$ と 同様に，特に有機リン系農薬で回収率が低かったことか

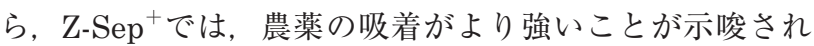
た。これは，他の報告例 ${ }^{9)}$ と同じ傾向であった。

一方, Z-Sep/C18 $(20 \mathrm{mg} / 50 \mathrm{mg})$ では良好な回収率お よび精度が得られた，Z-Sep/C18においても有機リン系農 薬等の回収率が低いという報告例があるが11)，本法では， 分散系として使用せず, SPEとしてカラムに積層させた

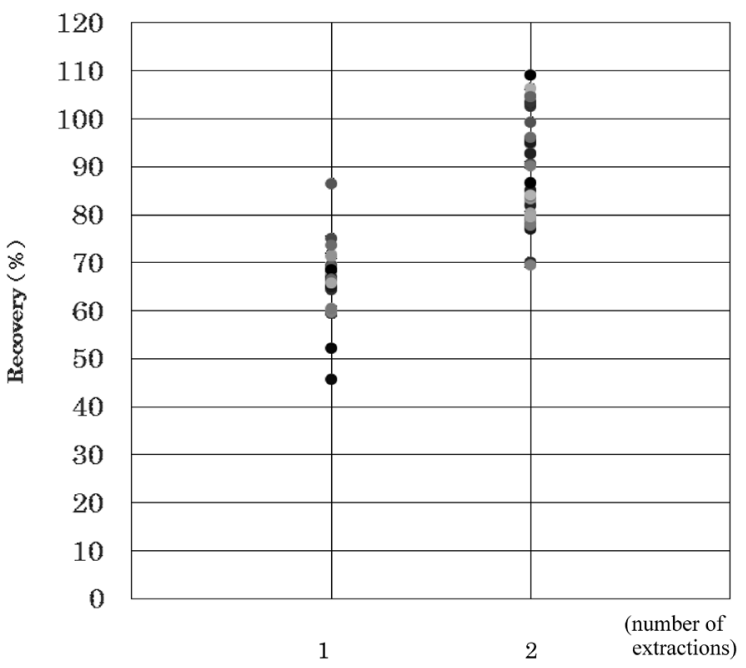

Fig. 2. Effect of the number of extractions on the recovery of 45 pesticides in soybean at the level of 0.1 $\mu \mathrm{g} / \mathrm{g}$

*Each value is the mean of 2 replications.
こと，および溶出液にトルエン含有アセトニトリル液を使 用したことが良好な回収率が得られた理由として考えられ た.また，Z-Sep/C18 (20 mg/50 mg) を追加したことで, 精製後に乾固した後の，乾固できない粘性の高い油滴と推 察される残留物の量が減少した。これは，このカラムの特 性として報告例 ${ }^{8)}$ 11) にある脂質除去効果の可能性が示唆 された.これらのことから, 今回はZ-Sep/C18 $(20 \mathrm{mg} / 50 \mathrm{mg})$ を選択し, 既法 $\left.{ }^{1}\right)$ のカラム上部に積層し て用いることとした（Fig. 1).

次に, Z-Sep/C18 $(20 \mathrm{mg} / 50 \mathrm{mg})$ を追加したことによ る精製効果を確認するために，0２5 ppbでの5点の検量 点で, 絶対検量線とマトリクス検量線の傾きを比較した. 両者の傾きの比からマトリクス効果について以下の評価指 標を用いて評価した。

\section{【評価指標】}

マトリクス効果 $a=b / c$

$b=$ マトリクス検量線の傾き, $c=$ 絶対検量線の傾き

大豆においてマトリクス効果が $0.8 \sim 1.2$ の範囲 ${ }^{12)}$ に抑

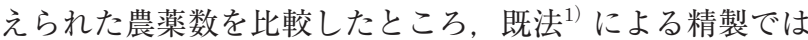
107 農薬中 78 農薬，Z-Sep/C18（20 mg/50 mg）を追加し た精製では 86 農薬となり，後者によって，よりマトリク スの影響が軽減された．白いんげん豆ではいずれも86農 薬であり，精製方法による差が見られなかったものの，レ ンズ豆では，79農薬が 85 農薬に，ひよこ豆では， 80 農薬 が 87 農薬にそれぞれ改善された（Fig. 3).

\section{3. 添加回収実験および妥当性評価}

大豆について， 既法 ${ }^{1)}$ を用いて $0.01 \mu \mathrm{g} / \mathrm{g}$ (アセフェート およびメタミドホスは $0.05 \mu \mathrm{g} / \mathrm{g})$ の濃度で, 添加回収実 験を行ったところ，真度（70～120\%）を満たしたもの は，107農薬中 51 農薬であった。また，そのほかの豆類 （レンズ豆，白いんげん豆およびひよこ豆）についても同

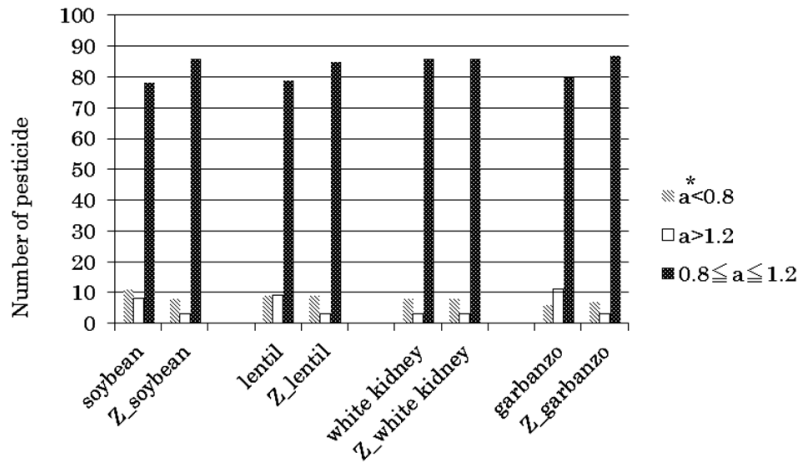

Fig. 3. Effect of clean up with each column on matrix effect of pulses

Non $\mathrm{Z}$ is the original column. $\mathrm{Z}$ is the original column plus Z-Sep/C18 (20 mg/50 mg).

*Each value is the mean of 3 replications.

$a$ : slope ratio between matrix-matched and solvent calibration. 


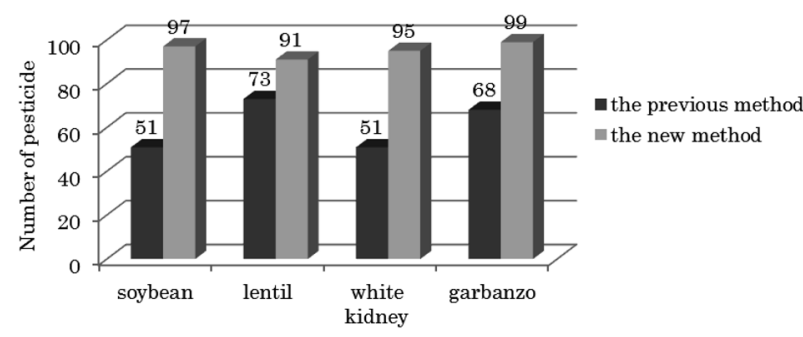

Fig. 4. Recovery test in pulses fortified with 107 kinds of pesticides at the level of $0.01 \mu \mathrm{g} / \mathrm{g}$

This graph shows the number of pesticide for which the recovery is between 70 and $120 \%$.

*Each value is the mean of 3 replications. The result for soybeans by the new method is based on the method validation guideline of the Ministry of Health, Labour and Welfare of Japan.

様に十分な真度が得られなかった。一方，本法を用い, 3 併行の予備的な添加回収実験を実施したところ，107農 薬中 100 農薬で真度の基準を満たした。

大豆以外の豆類 3 種（レンズ豆, 白いんげん豆およびひ

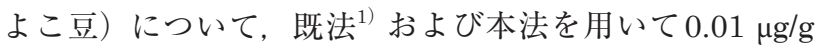
（アセフェートおよびメタミドホスは $0.05 \mu \mathrm{g} / \mathrm{g}$ ) の添加濃 度で, 3 併行の添加回収実験を実施した. その結果, 真度 が70〜 $120 \%$ の範囲で確認できた農薬は, レンズ豆におい て既法では 107 農薬中 73 農薬, 本法では 91 農薬であっ た. 同様に白いんげん豆では 51 農薬が 95 農薬, ひよこ豆 では 68 農薬が 99 農薬となり，本法での大幅な改善が見ら れた（Fig. 4）（Table S2）。一方, 低回収率であった農薬 には, ジクロトホス, メタミドホス, モノクロトホスと いった比較的極性が小さく, 溶出時間も速い有機リン系農 薬が確認できた. これらはマトリックス効果が認められ, 特に, イオン化抑制が顕著であったメタミドホスでは, 絶 対検量線における定量值が50\%前後であったが，マトリ クス検量線で定量した場合は, いずれの豆においても回収 率が $70 \%$ 以上に向上することが分かった.

大豆については, 本法を用いて, ガイドライン*1に 従って 2 濃度 $(0.01 \mu \mathrm{g} / \mathrm{g}$ ならびに $0.1 \mu \mathrm{g} / \mathrm{g}$ （アセフェート およびメタミドホスは $0.05 \mu \mathrm{g} / \mathrm{g}$ ならびに $0.5 \mu \mathrm{g} / \mathrm{g}))$, 試験 者 1 名, 2 併行, 5 日間での枝分かれ添加回収実験を実施 し, 真度, 併行精度および室内精度を算出した. なお, 定 量值の算出については, ピーク面積による絶対検量線法を 用いた (Table S3).

評価基準を満たしたものは, 107 農薬中 97 農薬であり, これらの農薬については定量分析を伴う検査が可能であっ た。なお，真度において評価基準を満たせなかった農薬に ついても十分な検出感度が得られていることから, 本法を 用いて豆類のスクリーニング検査が可能と考えられた.

\section{ま と め}

LC-MS/MSを用いた豆類中残留農薬の迅速分析法につ いて検討した。抽出はアセトニトリル $30 \mathrm{~mL}$ で 2 回行い,
塩析用塩化ナトリウム量を $2 \mathrm{~g}$ に設定した．精製には著者 らのオリジナルカラム ${ }^{1)}$ にZ-Sep/C18 (20 mg/50 mg) を 加えることで，マトリクス効果を改善した，妥当性評価ガ イドラインに従って本法の妥当性を評価したところ, 大豆 については，107農薬中 97 農薬でガイドライン*1のすべ てのパラメータについて評価基準を満たし，絶対検量線法 による定量が可能であることを確認できた。 また，本法を 他の豆類に適用したところ, 大豆と同様に十分な真度が確 保できた。本法は， 既法 ${ }^{1)}$ と同様に，使用する器具，溶媒 が少なく，作業工程も少ないことから，効率的かつ効果的 な豆類中残留農薬の日常検査法として適用できるものと考 える.

本論文の一部は, 日本食品衛生学会第 108 回学術講演会 （2015, 金沢）において発表した.

文献

1) Iwakoshi, K., Yasuhiro, T., Otsuka, K. et al. Studies on a rapid multi-residue analysis of pesticide in agricultural products by LC-MS/MS. J. Pestic. Sci., 55, 254-259 (2014).

2) Wang, J., Cheung, W., Chow, W. Ultra-high performance liquid chromatography/electrospray ionizationtandem mass spectrometry determination of 151 pesticides in soybeans and pulses. J. AOAC Int., 96, 1114-1133 (2013).

3) Fernandez Moreno, J. L., Arrebola Liebanas, F. J., Garrido Frenich A., Martinez Vidal J. L. Evaluation of different sample treatments for determining pesticide residues in fat vegetable matrices like avocado by low-pressure gas chromatography-tandem mass spectrometry l. J. Chromatogr. A, 1111, 97-105 (2006).

4) Nguyen, T. D. Lee, M. H. Rapid determination of 95 pesticides in soybean oil using liquid-liquid extraction followed by centrifugation, freezing and dispersive solid phase extraction as cleanup steps and gas chromatography with mass spectrometric detection. Microchem. J., 95, 113-119 (2010).

5) Koesukwaiwat, U., Lehotay S. J., Mastovska, K., Dorweiler K. J. Leepipatpiboon, N. Extension of the QuEChERS method for pesticide residues in cereals to flaxseeds, peanuts, and doughs. J. Agric. Food Chem., 58, 5950-5958 (2010).

6) Okihashi, M., Kitagawa, Y., Akutsu, K., Obana, H., Tanaka, Y. Rapid method for the determination of 180 pesticide residues in foods by gaschro matography/mass spectrometry and flame photometric detection. J. Pestic. Sci., 30, 368-377 (2005).

7）香川芳子．五訂食品成分表 2001. 東京，女子栄養大学 出版部, 2001, p. 50-57. (ISBN 4-7895-010-9)

8) Rajski, L., Lozano, A., Ucles, A., Ferrer, C., et al. Determination of pesticide residues in high oil vegetal commodities by using various multi-residue methods and clean-ups followed by liquid chromatography tandem mass spectrometry. J. Chromatogr. A, 1304, 109-120 (2013). 
9) Palenikova, A., Martinez-dominguez, G., Arrebola, F., et al. Multifamily determination of pesticide residues in soya-based nutraceutical products by GC/MS-MS. Food Chem., 173, 796-807 (2015).

10) Li, Y., Kelly, R. A., Lydy, M. J., et al. Development and comparison of two multi-residue methods for the analysis of select pesticides in honey bees, pollen, and wax by gas chromatography-quadrupole mass spectrometry. Talanta, 140, 81-87 (2015).
11) Sugitate, K., Saka, M. Decrease in the matrix enhancement effect on pesticides analysis with GC-MS using new types of solid-phase extraction column. J. Pestic. Sci., 40, 87-91 (2015).

12) Kollipara, S., Bende G., Agarwal, N., Varshney, B., Paliwal, J. International guidelines for bioanalytical method validation: a comparison and discussion on current scenario. Chromatographia, 73, 201-217 (2011). 